\title{
Meningkatkan Aktifitas Dan Prestasi Belajar Matematika Melalui Penerapan Metode Permainan di Kelas VI SDN 2 Bakan Kecamatan Janapria Kabupaten Lombok Tengah Tahun Pelajaran 2016/2017
}

\author{
Muksin \\ Kepala SDN 2 Bakan Kecamatan Janapria
}

\begin{abstract}
Abstrak; Hasil pengamatan di dalam kelas saat pembelajaran matematika berlangsung, siswa kelas VI cenderung pasif dan aktivitas belajar matematika siswa sangatlah kurang. Untuk pelajaran matematika nilai rata-rata yang diperoleh siswa kelas VI pada materi pengukuran berat yang merupakan materi sebelum dilakukannya penelitian ini adalah 50,37 dan persentase jumlah siswa yang mencapai standar ketuntasan belajar sebesar 33,33\%. Nilai ini sangatlah jauh dari persentase jumlah siswa yang mencapai standar ketuntasan belajar mengajar (SKBM) yang ditetapkan di SD Negeri 2 Bakan, yaitu sebesar 60\%. Penelitian tindakan kelas (PTK) ini dilaksanakan selama 2 bulan dengan menggunakan metode permaian dalam upaya meningkatkan aktivitas dan persetasi belajar matematika siswa kelas VI SDN 2 Bakan. Penelitian dilaksanakan dalam dua siklus masing-masing terdiri dari dua pertemuan melalui tahapan-tahapan sebagai berikut perencanaan, tindakan obervasi dan refleksi. Teknik pengumpulan data dilakukan melalui lembar pengamatan tiap pertemuan oleh observer untuk melihat data tentang aktivitas belajar, sementara data tentang hasil belajar diperoleh melalui nilai ulangan harian dan prestasi belajar matematika siswa di siklus 1, dan di siklus 2. Hasil yang diperoleh dari Penelitian Tindakan Kelas (PTK) melalui model metode permainan, memperlihatkan peningkatan hasil aktivitas siswa terutama pada aktivitas untuk menyiapkan tempat, bahan dan alat sebesar 55,56\%, aktivitas untuk mengungkapkan gagasan sebesar 66,67\% dan untuk aktivitas membaca aturan permainan dan buku-buku mengalami sebesar 74,04\%. Berdasarkan data prestasi belajar matematika siswa diperoleh nilai rata-rata kelas pada siklus I sebesar 69,62 meningkat menjadi 73,51 pada siklus II. Presentase jumlah siswa yang mencapai standar ketuntasan juga meningkat pada siklus I sebesar 88,88\% (Kategori Baik), meningkat menjadi 100\% (Kategori Istimewa) pada siklus II.
\end{abstract}

\section{Kata kunci : Metode Permainan, Aktivitas belajar, Perstasi Belajar Matematika}

\section{PENDAHULUAN}

Pembelajaran matematika merupakan interaksi timbal balik antara siswa dengan guru dan antara siswa dengan siswa yang melibatkan berbagai komponen untuk mencapai tujuan pembelajaran matematika. Pembelajaran matematika di sekolah terus diupayakan dalam rangka meningkatkan kualitas prestasi belajar siswa. Berbagai cara terus dilakukan, salah satunya dilakukan dengan mensinergikan komponen-komponen yang terlibat dalam pembelajaran. Komponen yang terlibat dalam pembelajaran tersebut adalah tujuan, bahan pelajaran (materi), kegiatan pembelajaran, metode, alat dan sumber serta evaluasi.

Salah satu materi pada pelajaran matematika adalah Geometri dan pengukuran. Tujuan diberikannya materi tersebut adalah siswa mampu menentukan cara menghitung berat suatu benda dalam kegiatan sehari-hari. Indikator yang harus dicapai olah siswa adalah dapat menggunakan kesetaraan satuan dalam perhitungan, melakukan hitungan berat dengan menggunakan alat hitung satuan berat. Jika tujuan dari materi ini dapat tercapai dengan maksimal maka sangatlah bermanfaat bagi siswa sebagai bekal selepas mereka dari bangku sekolah.

Terdapat beberapa permasalahan yang ditemukan pada saat mempelajari materi ini. Diantaranya adalah kekurangpahaman siswa terhadap soal yang diberikan, karena pada umumnya soal berbentuk cerita dan mengandaikan siswa ke dalam situasi ekonomi tertentu. Ketidaktelitian siswa dalam menyelesaikan permasalahan, karena untuk menyelesaikan soal diperlukan rumus-rumus 
yang dihafalkan. Kurangnya penguasaan siswa terhadap proses perhitungan, karena dalam proses perhitungan menggunakan satuan berat. Sebagian besar siswa menganggap bahwa materi tersebut sangatlah membosankan karena dalam kenyataannya siswa tidak berada dalam situasi tersebut dan nilai sesungguhnya tidaklah sebesar nilai yang dihitung.Pada umumnya metode yang digunakan guru dalam menyampaikan pelajaran adalah dengan metode ekspositori, yaitu dengan memaparkan informasi yang dianggap penting untuk siswa di awal pelajaran, memberikan definisi dan rumus, menjelaskan contoh soal dan cara pengerjaannya, memberikan soal-soal latihan untuk dikerjakan siswa dan kemudian memeriksa pekerjaan siswa di akhir pelajaran. Beberapa guru merasa cocok dengan metode tersebut, namun jika guru mengajar dengan metode yang sama pada setiap pertemuan maka tidak jarang akan ditemui siswa yang bosan untuk mempelajari materi ini, terjadi penurunan aktivitas belajar yang mengakibatkan menurunnya prestasi belajar matematika siswa.

Hasil pengamatan di dalam kelas saat pembelajaran matematika berlangsung, siswa kelas VI cenderung pasif dan aktivitas belajar matematika siswa sangatlah kurang. Hal ini terlihat dari tidak adanya respon saat Tanya jawab berlangsung, tidak berminatnya siswa untuk menyelesaikan soal matematika dan banyak siswa yang bersikap acuh. Jika guru bertanya tentang sejauh mana pemahaman yang didapat mereka mengangguk tanda paham, tetapi jika diberkan satu saja permasalahan mereka tidak dapat menyelesaikannya. Untuk pelajaran matematika nilai rata-rata yang diperoleh siswa kelas VI pada materi Mengumpulkan dan membaca data yang merupakan materi sebelum dilakukannya penelitian ini adalah 65,00 dan persentase jumlah siswa yang mencapai standar ketuntasan belajar sebesar $35,29 \%$ atau 6 dari 17 orang siswa . Nilai ini sangatlah jauh dari persentase jumlah siswa yang mencapai Kriteria Ketuntasan Minimal (KKM) yang ditetapkan di SDN 2 Bakan
Kecamatan Janapria Kabupaten Lombok Tengah yaitu sebesar $85 \%$.

Jika situasi pembelajaran tersebut dibiarkan dan tidak segera diatasi oleh guru maka akan berdampak negatif terhadap prestasi belajar matematika secara keseluruhan. Salah satu upaya guru untuk meningkatkan kembali aktivitas dan prestasi belajar matematika siswa dalam mempelajari materi Geometri dan pengukuran adalah dengan melakukan perbaikan metode pembelajaran yang disesuaikan dengan komponen pembelajaran lainnya. Salah satu metode yang dapat guru gunakan adalah metode permainan. Sudjana (2000:138) mengungkapkan bahwa penyajian teknik permainan yang baik akan menarik perhatian peserta didik sehingga menimbulkan suasana yang mengasyikan tanpa menimbulkan kelelahan. Hal ini senada diungkapkan Djaramah (2002:139) salah satu upaya guru dalam memotivasi siswa adalah dengan menggunakan simulasi dan permainan. Hal ini dapat meningkatikan interksi, menyajikan gambaran yang jelas mengenai kehidupan sebenarnya dan melibatkan siswa secara langsung dalam pembelajaran.

Dalam materi Geometri dan pengukuran metode permainan yang dapat digunakan adalah permainan jual beli. Yaitu metode permainan yang menetapkan agar pembelajaran bertitik tolak pada hal-hal konkrit bagi siswa. Hal ini dilakukan dengan memanipulasi benda-benda seperti uang mainan, timbangan, barang-barang dagangan, barang-barang yang menggunakan kemasan dan barang-barang yang tidak menggunakan kemasan ke dalam bentuk permainan.

Menekankan keterampilan dalam memainkan peran sebagai pedagang, penjual, pegawai pajak dan pengawas bank. Selanjutnya mendiskusikan permasalahan yang ditemui dan menemukan sendiri cara menyelesaikan masalahnya dengan baik. Hal ini dapat memotivasi siswa untuk bersungguh-sungguh dalam mengikuti pelajaran. Kesungguhan dalam belajar dengan sendirinya akan memacu siswa untuk dapat meningkatkan aktivitas belajar siswa. Jika aktivitas dapat diciptakan dalam pembelajaran 
matematika, maka suasana saat pembelajaran akan lebih dinamis, tidak membosankan dan benar-benar menjadi pusat aktivitas belajar yang maksimal. Aktivitas yang tercipta akan mendorong siswa untuk berpikir dan berusaha untuk mendapatkan prestasi belajar matematika yang memuaskan.

\section{KAJIAN PUSTAKA}

Djaramah dan Aswan (2002:82) mengungkapkan bahwa salah satu usaha yang tidak pernah guru tinggalkan adalah bagaimana memahami kedudukan metode sebagai salah satu komponen yang ikut ambil bagian bagi keberhasilan pembelajaran.

Kedudukan metode dalam pembelajaran tersebut adalah:

1. Metode sebagai alat motivasi ekstrinsik, metode berfungsi sebagai alat perangsang dari luar yang dapat membangkitkan belajar seseorang.

2. Metode sebagai strategi pembelajaran, metode mengajar adalah strategi pengajaran sebagai alat untuk mencapai tujuan yang diharapkan.

3. Metode sebagai alat untuk mencapai tujuan, metode sebagai alat yang efektif untuk mencapai tujuan pembelajaran.

Dari kedudukan metode pembelajaran di atas, dapat diambil satu definisi tentang metode tentang metode pembelajaran yaitu strategi pembelajaran yang berfungsi sebagai alat perangsang dari luar yang dapat membangkitkan belajar seseorang dan merupakan alat yang efektif untuk mencapai tujuan pembelajaran.

Metode pembelajaran yang mengarah pada teori tersebut adalah metode permainan. Sudjana (2000:138) mengungkapkan bahwa metode permainan adalah suatu metode yang digunakan untuk menyampaikan informasi kepada para peserta didik dengan menggunakan simbol-simbol atau alat-alat komunikasi lainnya. Berkenaan dengan pelajaran matematika, Hidayat (2004:16) mengungkapkan bahwa metode permainan matematika adalah setiap sumber hiburan yang mempunyai tujuan kognitif khusus yang dapat diukur dan tujuan afektif khusus yang dapat diamati. Suherman dan Udin (1999:258) mengungkapkan bahwa permainan matematika adalah suatu kegiatan yang menggembirakan yang dapat menunjang tercapainya tujuan intruksional pengamatan matematika.

Metode permainan matematika adalah suatu metode pembelajaran yang menetapkan agar pembelajaran bertitik tolak dari hal-hal konkrit bagi siswa, menekankan keterampilan dalam memainkan peran, berdiskusi, berargumentasi sehingga merangsang cara berfikir logis siswa untuk dapat menemukan sendiri dan menggunakan matematika untuk dapat menyelesaikan masalah dengan baik. Zoltan P. Dienes (dalam Suherman dan Udin, 1999:175) mengemukakan bahwa tiap-tiap konsep dalam matematika yang disajikan dalam bentuk konkrit akan dapat dipahami dengan baik. Benda-benda dalam bentuk permainan akan sangat berperan bila dimanipulasi dengan baik. Benda-benda ini dapat memelihara dan meningkatkan cara berfikir logis yang telah dimiliki siswa.

Dalam materi Geometri dan pengukuran metode permainan matematika yang dapat digunakan adalah permainan jual beli. Pada permainan jual beli siswa diberi peran yang harus dimainkan sesuai dengan aturan yang telah ditetapkan, mendiskusikan masalahmasalah yang ditemui dalam permainan, dan kemudian menentukan penyelesaiannya. Hal ini dapat merangsang pemikiran siswa secara logis. Pada permainan pengukuran dan jual beli, siswa dihadapkan pada benda-benda nyata yaitu uang, timbangan, barang-barang dagangan, barang-barang yang menggunakan kemasan dan barang-barang yang tidak menggunakan kemasan. Benda-benda tersebut dapat memelihara dan meningkatkan cara berfikir logis yang telah dimiliki siswa.

Bermain memiliki tahapan-tahapan tersendiri. Zoltan P. Dienes (dalam Suherman dan Udin, 1999:176) membagi 6 tahapan bermain, yaitu:

1. Permainan bebas (free play)

Yaitu tahap belajar konsep yang aktivitasnya tidak terstruktur dan tidak diarahkan.

2. Permainan yang disertai aturan (Games) Yaitu tahap belajar meneliti pola-pola dan keteruturan yang terdapat dalam konsep tertentu. 
3. Permainan Kesamaan sifat (Suarching for Communities)

Yaitu tahap belajar menentukan sifat-sifat kesamaan dalam permainan yang sedang diikuti.

4. Representasi

Yaitu tahap belajar menyimpulkan kesamaan sifat yang yang terdapat dalam situasi-situasi yang dihadapi.

5. Simbolisasi

Yaitu tahap belajar merumuskan representasi dengan menggunakan symbol matematika atau melalui perumusan verbal.

6. Formalisasi

Yaitu tahap belajar mengurutkan sifat sifat konsep dan kemudian merumuskan sifatsifat baru dari konsep tersebut.

Penerapan 6 tahapan belajar Dienes dalam permainan jual beli adalah siswa berhadapan dengan unsur-unsur dalam interaksinya dengan lingkungan belajar. Lingkungan belajar ini dapat berupa pasar, toko, kantor pajak atau bank. Siswa secara bebas mengamati aktivitas-aktivitasnya yang terjadi. Hal ini dapat mempersiapkan siswa untuk memahami konsep Geometri dan pengukuran . Siswa yang telah memahami konsep tersebut dapat memulai permainan dengan aturan-aturan yang telah ditetapkan. Siswa melakukan simulasi seperti berdagang, membeli barang, menjual barang. Hal ini dapat mengajak siswa untuk mengenal dan memikirkan pola-pola yang terdapat dalam konsep Geometri dan pengukuran. Dari simulasi yang dilakukan, siswa dapat menemukan sifat-sifat kesamaan antara permainan yang dilakukan dengan konsep Geometri dan pengukuran. Misalnya dalam jual beli seorang pedagang mengalami keuntungan atau kerugian, pada saat membeli barang dikenai diskon atau rabat, pada saat penimbangan barang diketahui berat brutto, netto dan tara.

\section{Prestasi Belajar}

Prestasi belajar merupakan aktualisasi dari potensi siswa melalui tes hasil belajar. Prestasi belajar merupakan perubahan perilaku dalam individu yang dimanifestasikan ke dalam pola sikap dan tingkah laku (afektif), keterampilan dan komunikasi (psikomotor) serta pengenalan pengetahuan, perkembangan kemampuan dan keterampilan intelektual (kognitif) sebagai hasil belajar yang disadari dan dicapai setelah melakukan pembelajaran pada periode tertentu. Standar keberhasilan prestasi belajar dapat bersifat intrinsic yang berarti ditetapkan sendiri sesuai dengan kurikulum yang berlaku atau menurut standar yang telah ditetapkan juga dapat bersifat ekstrinsik yang merupakan tuntutan dari lingkungan sekitar. Prestasi belajar dapat dinyatakan dalam bentuk symbol, angka, huruf maupun suatu kalimat.Menurut Djamarah (2002:143) faktor-faktor yang mempengaruhi prestasi belajar, yaitu:

Faktor-faktor yang mempengaruhi prestasi belajar tersebut saling berkaitan. Misalnya dalam faktor instrumental, kurikulum adalah a plan for learning yang merupakan unsur substansial dalam pendidikan. Setiap guru harus mempelajari dan menjabarkan isi kurikulum kedalam program yang lebih rinci dan jelas sasarannya. Program disusun berdasarkan potensi sekolah yang tersedia baik tenaga guru, finansial, maupun sarana dan prasarana. Program akan berhasil jika didukung oleh tenaga guru yangmemadai. Setiap guru memegang mata pelajaran yang sesuai dengan latar belakang pendidikannya dan bertanggung jawab membina dan membimbing setiap siswa agar mencapai prestasi optimal dalam belajar. Program juga akan lebih baik jika didukung oleh fasilitas, siswa akan dapat belajar dengan baik dan menyenangkan jika sekolah dapat memenuhi segala kebutuhan belajar siswa. Faktor instrumental sebagai faktor dari luar juga erat kaitannya dengan faktor psokologis sebagai faktor dari dalam. Jiika faktor luar mendukung tetapi faktor psikologis sebagai faktor dalam tidak mendukung maka faktor luar akan kurang signifikan.

\section{METODE PENELITIAN}

\section{A. Subjek Penelitian}

Subjek penelitian ini adalah siswa kelas VI semester I SDN 2 Bakan, 
Kecamatan Janapria Kabupaten Lombok Tengah Tahun Pelajaran 2016/2017 dan proses-proses interaktif antara guru dengan siswa, siswa dengan siswa selama pelaksanaan pembelajaran matematika dengan menggunakan metode permainan berlangsung.

Penelitian ini dilaksanakan di SDN 2 Bakan Kecamatan Janapria Kabupaten Lombok Tengah, Sedangkan waktu penelitian dilaksanakan pada Bulan Agustus sampai dengan Bulan Oktober 2016 pada siswa Kelas VI semester I Tahun Pelajaran 2016/2017.

\section{B. Metode Penelitian}

Tujuan penelitian ini adalah untuk mengetahui adanya peningakatan aktifitas dan prestasi belajar matematika siswa kelas VI semester I SDN 2 Bakan Kecamatan Janapria Kabupaten Lombok Tengah Tahun Pelajaran 2016/2017 pada materi Mengumpulkan dan membaca Data. Untuk mencapai tujuan tersebut maka diperlukan suatu upaya pembelajaran berupa metode permainan jual beli sebagai solusi praktis dan kontekstual tanpa mengabaikan hal-hal yang bersifat teoritik.

Berdasarkan pertimbangan tersebut, metode penelitian yang dianggap tepat adalah metode penelitian tindakan yang difokuskan pada situasi kelas yang lebih dikenal dengan Penelitian Tindakan Kelas (PTK) atau Classrrom Action Research (CAR). Sukardi (2004:211) mengungkapkan bahwa penelitian tindakan pada umumnya sangat cocok untuk meningkatkan kualitas subjek yang hendak diteliti. Sependapat dengan hal ini Madya (1994:12) mengungkapkan bahwa penelitian tindakan yang dimaksudkan untuk meningkatkan praktik tertentu ke dalam situasi kerja tertentu.

\section{Prosedur penelitian}

Prosedur yang digunakan dalam penelitian ini, mengembangkan sebagimana lazimnya dalam penelitian ini terdiri dari dua siklus dengan tahap-tahap kegiatan yang ditempuh pada tiap siklus meliputi empat kegiatan, yaitu : (1) Tahap perencanaan (paln), (2) Tahap pelaksanaan atau tindakan (action), (3) Tahap pengamatan (Observation), (4) Tahap Refleksi (Reflective).Secara operasional siklus penelitian tindakan kelas dapat dijelaskan sebagai berikut :

\section{Perencanaan (plan)}

Tahap perencanaan tindakan adalah langkah persiapan untuk :

(a) Mengidentifikasi aktifitas dan prestasi belajar matematika siswa kelas VI semester satu SDN 2 Bakan, Kecamatan Janapria Kabupaten Lombok Tengah Tahun Pelajaran 2016/2017.

(b) Menyusun rencana tindakan yang hendak dilakukan dalam penerapan metode permainan yaitu dengan menyusun rencana pembelajaran, menyusun aturan permainan, dan menyusun instrumen-instrumen yang akan digunakan.

(c) Menyiapkan sumber, alat dan bahan yang hendak digunakan. Pada siklus I dibutuhkan buku paket matematika kelas VI, LKS, kartu peranan sebagai penjual dan pembeli, uang mainan, timbangan, buku, pensil, tas dan penggaris yang kemudian akan digunakan sebagai barang dagangan. Siklus II dibutuhkan buku paket matematika VI, LKS, kartu peranan sebagai penjada toko dan konsumen, buku, pensil, tas dan penggaris yang kemudian akan digunakan sebagai barang dagangan, timbangan, gelas, beras, terigu dan gula pasir.

(d) Mengidentifikasi masalah-masalah yang terdapat pada siklus sebelumnya serta menetapkan pemecahan masalahnya untuk siklus berikutnya.

\section{Pelaksanaan (action)}

Tahap tindakan adalah kegiatan pelaksanaan penerapan metode permainan jual beli sesuai dengan rencana tindakan yang telah disusun sebelumnya. Pada siklus I tindakan yang dilakukan dimulai dengan membahas masalah sehari-hari dalam perdagangan untuk menanamkan konsep pada 
siswa tentang nilai keseluruhan, nilai per unit, dan nilai sebagian. Secara berkelompok siswa bermain jual beli dengan membagi peran, dua orang sebagai penjual dan dua orang sebagi pembeli kemudian melakukan jual beli dengan uang mainan sebagai alat pembayarannya. Sebagai acuan dalam bermain, siswa diberikan format tabel yang harus diisi sesuai dengan peran yang dimainkannya. Membahas beberapa catatan yang dibuat oleh siswa selama permainan jual beli dan menyimpulkan materi yang telah dipelajari.

Pada siklus II tindakan yang dilakukan dimulai dengan membahas masalah sehari-hari dalam perdagangan untuk memainkan konsep pada siswa tentang satuan berat, ton, kwintal, kg, dag, gram, cm, mg. Secara berkelompok siswa bermain jual beli dengan membagi peran, dua orang sebagai penjaga toko dan dua orang sebagai konsumen kemudian melakukan jual beli dengan menggunakan uang mainan sebagai alat pembayarannya. Sebagai acuan dalam bermain, siswa diberikan tabel format yang harus diisi sesuai dengan peran yang dimainkannya. Melakukan penimbangan beberapa barang dengan wadah/kemasannya dan penimbangan barang tanpa wadah/kemasannya dan mencatat dalam format tabel. Membahas beberapa catatan yang dibuat oleh siswa selama permainan jual beli dan menyimpulkan materi yang telah dipelajari Pada setiap akhir siklus dilakukan evaluasi dengan tes prestasi belajar matematika siswa untuk mengetahui peningkatan prestasi belajar matematika siswa kelas VI semester satu SDN 2 Bakan, Kecamatan Janapria Kabupaten Lombok Tengah Tahun Pelajaran 2016/2017.

\section{Observasi}

Tahap pengamatan adalah kegiatan langsung maupun tidak langsung untuk merekam semua peristiwa yang terjadi pada saat proses tindakan. Pengamatan ini digunakan untuk mengetahui peningkatan aktifitas belajar matematika siswa kelas VI semester satu SDN 2 Bakan, Kecamatan Janapria Kabupaten Lombok Tengah Tahun Pelajaran 2016/2017.

\section{Refleksi}

Tahap Refleksi adalah kegiatan mengkaji hasil observasi dan merenungkan kembali proses-proses tindakan dengan berbagai permasalahannya. Dalam tahap Refleksi ini diolah lembar observasi, jurnal siswa dan tes prestasi belajar matematika siswa yang didapat dari tahap tindakan kemudian menganalisanya untuk melihat peningkatan aktivitas dan prestasi belajar matematika siswa kelas VI semester I SDN 2 Bakan Kecamatan Janapria Kabupaten Lombok Tengah Tahun Pelajaran 2016/2017. Kegiatan Refleksi ini dilakukan untuk menentukan, merekomendasi dan mendapatkan masukan bagi perbaikan rencana selanjutnya.

\section{Teknik Pengumpulan Data}

Untuk keperluan pengumpulan data tentang proses dan hasil yang dicapai dipergunakan :

1. Nilai Ulangan Harian Matematika Siswa

Nilai ulangan harian matematika siswa didapat dari nilai ulangan pada materi bilangan bulat yaitu materi sebelum dilakukannya penelitian ini. Nilai ulangan harian matematika siswa ini dimaksudkan untuk memperoleh gambaran tentang prestasi belajar matematika siswa kelas VI semester satu SDN 2 Bakan tahun ajaran 2016/2017. Nilai ini kemudian dijadikan prestasi awal dalam penelitian.

Dari ulangan harian yang dilakukan oleh siswa VI semester I SDN 2 Bakan , Kecamatan Janapria Kabupaten Lombok Tengah Tahun Pelajaran 2016/2017 pada materi Mengumpulkan dan membaca data diperoleh nilai rata-rata sebesar 50,37 dan persentasenya siswa yang mencapai standar ketuntasan belajar sebesar 35,29\%.

2. Tes Prestasi Belajar

Prestasi belajar merupakan perubahan perilaku dalam individu yang dimanfaatkan kedalam pola pengetahuan sebagai hasil belajar yang disadari dan dicapai setelah melakukan pembelajaran pada materi Geometri dan pengukuran dengan metode permainan jual beli. 
Standar keberhasilan prestasi belajar bersifat instrinsik yang berarti ditetapkan sendiri sesuai dengan kurikulum yang berlaku. Prestasi ini dinyatakan dalam bentuk angka puluhan. Tes prestasi belajar yang digunakan dalam penelitian ini terbentuk uraian karena dengan tes uraian akan terlihat kemampuan dan proses berpikir siswa yang sebenarnya terhadap materi yang disampaikan. Tes prestasi belajar ini diberikan setiap akhir siklus, untuk siklus satu memuat dua puluh butir soal, untuk siklus II memuat sepuluh butir soal. Tes prestasi ini dimaksudkan untuk mengetahui peningkatan prestasi belajar matematika kelas siswa VI semester I SDN 2 Bakan Kecamatan Janapria Kabupaten Lombok Tengah Tahun Pelajaran 2016/2017, setelah dilakukannya pembelajaran matematika dengan metode permainan jual beli.

3. Lembar Observasi

Lembar observasi berisi daftar jenis aktifitas belajar siswa yang mungkin timbul dan akan diamati selama pembelajaran matematika dengan permainan jual beli berlangsung. Hasil dari lembar observasi ini disajikan data aktifitas belajar matematika siswa dan bahan Refleksi untuk perbaikan tiap siklus.

4. Jurnal Siswa

Jurnal siswa diberikan di setiap akhir siklus dengan maksud untuk merekam semua peristiwa yang terjadi pada saat proses tindakan, kendala tindakan, langkah-langkah tindakan, permasalahan lain yang mungkin timbul selama pelaksanaan tindakan serta gagasan untuk siklus berikutnya

5. Foto

Foto digunakan untuk merekam peristiwa penting pada proses tindakan. Hasil foto ini dapat didskusikan dengan guru dan siswa sehingga dapat memberikan andil dalam perbaikan siklus selanjutnya.

\section{E. Teknik Analisis Data}

Teknik analisis data yang dilakukan dalam penelitian ini adalah sebagai berikut :
1. Data Aktifitas Belajar Matematika Siswa Data aktifitas belajar matematika siswa diperoleh melalui lembar observasi. Hasil observasi ini kemudian dianalisis untuk melihat aktifitas-aktfitas apa saja yang muncul selama pembelajaran matematika dengan metode permainan jual beli berlangsung.Untuk melihat tingkat aktifitas belajar matematika siswa, selanjutnya dilakukan penskoran terhadap aktifitas-aktifitas yang muncul dengan cara menghitung persentase dari tiap-tiap aktifitas selama pembelajaran matematika dengan metode permainan berlangsung

\section{F. Indikator keberhasilan}

1. Ketuntasan secara perorangan Berdasarkan petunjuk pelaksanaan belajar mengajar kurikulum 2006 (Depdikbud, 2006), yaitu seorang siswa telah tuntas belajar bila siswa telah memperoleh nilai 70 .

2. Sedangkan ketuntasan secara Klasikal apabila prosentase ketuntasan secara klasikal telah mencapai $85 \%$ dari jumlah siswa.

\section{HASIL PENELITIAN DAN PEMBAHASAN \\ Siklus I}

\section{a. Perencanaan}

Berdasarkan permasalahan melalui data pada observasi awal, kemudian dibuat perencanaan tindakan untuk siklus I. Adapun tahap perencanaan tindakan untuk siklus I adalah:

1) Menyusun rencana pembelajaran

2) Menyusun aturan permainan

3) Membuat soal tes prestasi belajar matematika siswa yang memuat materi tentang Mengumpulkan dan membaca data.

4) Membuat lembar observasi dan jurnal siswa.

5) Mempersiapkan sumber, alat dan bahan berupa buku paket matematika kelas VI,LKS, kartu peranan sebagai penjual dan pembeli, uang mainan, timbangan, buku, pensil, ballpoint, tas dan penggaris yang akan digunakan sebagai barang dagangan.

6) Mempersiapkan foto untuk dokumentasi. 


\section{b. Pelaksanaan}

Pelaksanaan pembelajaran siklus I dilaksanakan pada hari Kamis, tanggal 8 September 2016, di SDN 2 Bakan, Kecamatan Janapria, Kabupaten Lombok Tengah, Pelaksanaan pembelajaran dilaksanaakan sesuai dengan rencana pembelajaran.

\section{c. Observasi}

Pertemuan pertama dilaksanakan pada hari Kamis tanggal 8 September, 2016. Sebelum pelajaran dimulai, guru meminta beberapa siswa maju ke depan kelas untuk menceritakan pengalaman dalam mengukur suatu berat. Misalnya mengukur berat badan, mengukur tinggi badan, membandingkan berat benda sejenis dan tidak sejenis, mengidentifikasikan jenis-jenis suatu benda kedalam ukuran berat, mengurutkan benda yang paling ringan hingga paling berat. Namun beberapa menit berlalu tidak ada satu pun siswa yang memberanikan diri untuk ke depan kelas, guru mempertegas kembali dengan memanggil nama siswa secara acak. Baru setelah itu siswa mau bercerita di depan kelas dengan malu-malu.

Setelah siswa mempunyai gambaran mengenai kegiatan pengukuran, guru melakukan tanya jawab yang mengarahkan siswa ke dalam materi. Misalnya "Ibu membeli 2 karung beras masing-masing beratnya $50 \mathrm{Kg}$, berapakah jumlah berat keseluruhan karung beras tersebut?". Tanya jawab terus dilakukan sampai siswa dapat menjabarkan konsep jumlah barang kedalam suatu rumus. Kemudian guru memberikan satu contoh. Dan contoh tersebut guru menginformasikan mengenai identifikasi jenis-jenis suatu benda kedalam ukuran berat. Pertemuan pertama ditutup dengan menyimpulkan materi yang telah dipelajari, mengungkapkan gagasan mengenai permainan yang akan dilaksanakan pada pertemuan berikutnya dan memberikan tugas untuk menyiapkan pada pertemuan berikutnya dan memberikan tugas untuk menyiapkan sumber, bahan dan alat yang akan digunakan dalam permainan pengkuran. Pada pertemuan pertama ini, aktifitas belajar matematika masih di dominasi oleh guru dan sesekali mengungkapkan gagasan.

\section{d. Refleksi}

Selama pembelajaran berlangsung pada siklus I, observer melakukan observasi yang dilakukan siswa di kelas melalui pretes dan postes. Secara garis besar jumlah siswa yang melakukan aktifitas belajar matematika siswa belum optimal. Ke sepuluh aktifitas belajar matematika siswa belum semuanya dapat dilakukan oleh siswa. Terutama untuk aktifitas menyiapkan tempat, sumber, bahan dan alat sebesar $11,11 \%$, mengungkapkan gagasan $25,93 \%$ dan membaca aturan permainan dan buku sebesar 29,63\%. Aktifitas lainnya sudah tergolong ke dalam kategori sedang.

\section{Siklus II}

\section{a. Perencanaan}

Berdasarkan hasil tes prestasi belajar matematika siswa dan rerfleksi pada siklus I, maka ada beberapa hal yang harus diperhatikan untuk meningkatkan aktifitas dan prestasi belajar matematika siswa dengan menggunakan metode permainan jual beli. Dengan demikian perencanaan tindakan untuk siklus II adalah sebagai berikut :

1) Menyusun rencana pembelajaran.

2) Menyusun aturan permainan

3) Membuat soal tes prestasi belajar matematika siswa.

4) Membuat lembar observasi

5) Mempersiapkan sumber, alat dan bahan berupa buku paket matematika kelas VI, LKS, kartu peranan, sebagai pedagang dan pembeli serta uang mainan.

6) Mempersiapkan foto untuk dokumentasi

\section{b. Observasi}

Pertemuan keempat dilaksanakan pada hari Kamis tanggal 15 september 2016.Sebelum pelajaran dimulai, guru meminta siswa untuk menceritakan pengalamannya berbelanja di pasar?. Tanpa disebutkan nama, siswa bergantian maju ke depan kelas untuk menceritakan pengalamannya. Kemudian guru melakukan Tanya jawab mengenai aktifitas berbelanja di pasar untuk mengetahui pemahaman siswa 
tentang cara menghitung berat suatu benda dan perbandingan berat beberapa buah benda. Siswa terlihat antusias dalam menjawab setiap soal yang dikemukakan oleh guru. Terlihat dari siswa yang menunjuk tangan dan saling berebut dalam menjawab. Kemudian guru memberikan satu contoh. Guru membiarkan siswa mengerjakan contoh tersebut dengan bantuan buku-buku yang menunjang. Setelah dianggap cukup guru bersama siswa membahas soal tersebut hingga benar-benar paham mengenai satuan berat, ton, kwintal, $\mathrm{kg}$, dag, gram, cm, mg.

Pertemuan keempat ditutup dengan menyimpulkan materi yang telah dipelajari, mengungkapkan gagasan permainan yang akan dilaksanakan pada pertemuan berikutnya dan memberikan tugas untuk menyiapkan sumber, bahan dan alat yang akan digunakan dalam permainan jual beli.Pada pertemuan keempat ini, aktifitas belajar matematika siswa terlihat aktif dimulai dari mendengarkan penjelasan guru, mengungkapkan gagasan, mengerjakan soal dan menyimpulkan materi.

Pertemuan ke lima dilaksanakan pada hari Kamis tanggal 22 september 2016 Pertemuan ini adalah pelaksanaan permainan jual beli. Walaupun dilaksanakan di dalam ruangan siswa tetap semangat dalam melaksanakan permainan. Sebelum permainan dimulai terlebih dahulu guru memberikan informasi mengenai tujuan dari permainan kemudian bersama siswa menyiapkan tempat, sumber, bahan dan alat yang akan digunakan. Siswa dibagi ke dalam beberapa kelompok satu kelompok terdiri dari 4-5 orang siswa. Secara berkelompok siswa bermain jual beli dengan membagi peran, satu orang sebagai penjual, satu orang sebagai pelayan toko dan dua orang sebagai konsumen kemudian melakukan permainan dengan uang mainan sebagai alat pembayarannya. Sebagai acuan dalam bermain, siswa diberikan format table dalam aturan permainan yang harus diisi sesuai dengan peran yang dimainkannya. Siswa tampak menghayati peran yang dimainkannya, di sela permainan terdengar siswa mengungkapkan gagasannya kepada guru "Nanti kalau saya besar saya mau jadi Pedagang, bu?".

Setelah permainan usai, siswa bersama kelompoknya mendiskusikan catatan yang diperoleh selama permainan. Guru dengan teliti memeriksa hasil dari permainan, memeriksa tabel dan menyesuaikan dengan peran yang dimainkan. Kemudian guru membahas beberapa catatan yang dibuat oleh siswa tersebut dan bersama-sama menyimpulkan materi yang telah dipelajari. Pada pertemuan kelima ini aktifitas belajar matematika siswa sudah aktif. Selama permainan berlangsung keadaan kelas terlihat tertib. Siswa mulai asyik dengan permainannya dengan mengikuti aturan yang telah ditetapkan.Pertemuan ke enam pada hari Kamis tanggal 29 september 2016 ini adalah pertemuan terakhir pada siklus II maka untuk mengetahui prestasi belajar matematika siswa diadakan tes prestasi belajar matematika yang ke dua.

\section{e. Refleksi}

Pesan dan kesan yang dirasakan oleh siswa diberikan jurnal siswa. Dan jurnal siswa diperoleh pendapat bahwa sebagian besar siswa menyenangi pembelajaran matematika dengan metode permainan. Berdasarkan hasil penelitian pada siklus II, aktivitas dan prestasi belajar matematika siswa mengalami peningkatan yang signifikan dan indikator sudah dapat tercapai. Dengan demikian, penelitian ini terhenti pada siklus II.

\section{B. Pembahasan}

Berdasarkan data yang didapat dari observasi, berikut adalah grafik aktivitas belajar matematika siswa pada setiap siklus.Secara umum aktivitas belajar matematika siswa tiap siklus mengalami peningkatan. Aktivitas belajar matematika siswa yang masih rendah pada siklus I antara lain menyiapkan tempat, bahan dan alat sebesar $11,11 \%$, mengungkapkan gagasan sebesar 25,93\% dan membaca aturan permainan dan buku-buku sebesar 29,63\% aktivitas-aktivitas tersebut tergolong ke dalam kategori kurang. Sementara pada siklus II, aktivitas belajar matematika siswa mengalami peningkatan yang cukup baik yaitu menyiapkan tempat, bahan dan alat 
sebesar 66,67\%, mengungkapkan gagasan sebesar 55,56\% dan untuk aktivitas membaca aturan permainan dan buku-buku mengalami peningkatan yaitu sebesar $74,04 \%$ yang tergolong ke dalam kategori sedang.Dengan demikian seluruh aktivitas belajar matematika siswa diperoleh nilai rata-rata kelas pada siklus I sebesar 69.59 mengalami peningkatan sebesar 2,47 pada siklus II menjadi 72,06

Selain rata-rata kelas yang meningkat diperoleh pula persentase jumlah siswa yang mencapai standar ketuntasan belajar pada siklus I sebesar $82,35 \%$ meningkat menjadi $94,12 \%$ pada siklus II dan termasuk dalam kategori baik sekali.

\section{KESIMPULAN DAN SARAN}

\section{A. Kesimpulan}

Berdasarkan hasil penelitian menunjukan bahwa pembalajaran dengan menggunakan metode permainan di kelas VI Semester I SD Negeri 2 Bakan Kecamatan Janapria Kabupaten Lombok TengahTahun Pelajaran 2016/2017 , pada pembelajaran Matematika, mendorong siswa melakukan aktivitas belajar mengajar dengan baik sehingga memacu siswa untuk memperoleh prestasi belajar yang memuaskan. Dari 10 aktivitas yang diamati, 7 diantaranya sudah tergolong ke dalam kategori sedang dan 3 diantaranya termasuk ke dalam kategori kurang. Ketiga aktivitas tersebut naik secara bertahap pada setiap siklusnya, ketiga aktivitas tersebut adalah menyiapkan tempat, bahan dan alat sebesar 25,93\%, mengungkapkan gagasan sebesar $11,11 \%$ dan membaca aturan permainan dan buku-buku sebesar $29,63 \%$ dan masingmasing mengalami peningkatan, menjadi menyiapkan tempat, bahan dan alat sebesar 55,56\%, mengungkapkan gagasan sebesar $66,67 \%$ dan untuk aktivitas membaca aturan permainan dan buku-buku mengalami peningkatan yaitu sebesar $74,04 \%$.

Berdasarkan data prestasi belajar matematika siswa diperoleh nilai rata-rata kelas pada siklus I sebesar 69,59 meningkat menjadi 72,06 pada siklus II. Presentase jumlah siswa yang mencapai standar ketuntasan juga meningkat pada siklus I sebesar 82,35\% (Kategori Baik), meningkat menjadi 94,12\% ( Baik Sekali ) pada siklus II. Dengan demikian metode permainan dapat meningkatkan aktivitas dan prestasi belajar matematika siswa kelas VI Semester I SDN 2 Bakan Kecamatan Janapria Kabupaten Lombok Tengah Tahun Pelajaran 2016/2017.

Berdasarkan jurnal siswa diketahui dengan penggunaan metode permainan menjadikan pembelajaran lebih menyenangkan, belajar tidak terlalu tegang namun tetap berkonsentrasi. Siswa lebih cepat mengerti konsep Geometri dan pengukuran dengan menghayati peran yang dimainkan.

\section{B. Saran}

a. Metode permainan dapat digunakan guru sebagai variasi dalam metode pembelajaran

b. Dalam penggunaannya, sebaiknya guru merencanakannya dengan tujuan yang jelas, mempersiapkan hal- hal yang akan digunakan dengan maksimal, membantu siswa dalam melaksanakan permainan dan meminimalkan resiko buruk yang akan terjadi. Dengan demikian waktu yang digunakan dapat efisien dan permainan yang digunakan dapat efektif dan bermanfaat.

c. Dalam penyampaiannya guru harus tegas dan kreatif agar siswa tetap berada dalam aturan permainan yang ditetapkan dan memperbanyak latihan-latihan.

\section{DAFTAR PUSTAKA}

Agus Saputra. (2004). Membuat Aplikasi Absensi Dan Kuesioner untuk Panduan. Skripsi. PT. Elex Media

Djaramah, aswan. (2002). Psikologi Belajar. Jakarta : Rineka Cipta

Hamalik. 2005. Proses Belajar Mengajar. Jakarta: Bumi Aksara

Hidayat. 2004. Diktat Kuliah Teori Pembelajaran Matematika. Semarang:FMIPA UNNES.

Madya, Suarsih. 1994. Panduan Penelitian Tindakan. Yogyakarta : Lembaga Penelitian IKIP - Yogyakarta

Nana Sujana, (1991). Media Pengajaran. Pusat Penelitian dan Pembidangan Ilmu Lembaga Penelitian IKIP Bandung. Sinar Baru 
Sardiman. 2004. Interaksi dan Motivasi Belajar Mengajar. Jakarta : PT Grafindo

Sudjana. 2000. Metode dan Teknik Pembelajran Partisipatif. Bandung : Falah Production

Suherman dan Udin, S, dkk. (1999). Strategi

Belajar Mengajar. Jakarta: Universitas Terbuka. 